\title{
Viajeros españoles en portugal en el siglo XVIII: Entre el conocimiento y la experiencia
}

\author{
María José Ortega Chinchilla[1]
}

\section{Resumen}

El objetivo que me planteo en este trabajo es doble: por una parte pretendo reflexionar sobre el fenómeno del viaje en Europa en el siglo XVIII, qué significados adquirió y con qué nociones se identificaba; y, en segundo lugar, mi intención ha sido la de recuperar los relatos y las experiencias de aquellos viajeros españoles que se internaron en el país vecino. En este sentido, me detendré en determinar en esta segunda parte cuál ha sido el tratamiento historiográfico de este grupo de viajeros - escaso y mal conocido - para cerrar con un análisis sobre la utilidad que puede tener el relato de dichas vivencias y experiencias viajeras en Portugal para la Historia de la vida cotidiana.

Palabras clave: viaje; siglo XVIII; vida cotidiana.

\section{Viajantes espanhóis em Portugal no século XVIII: entre o conhecimento e a experiência}

\section{Resumo}

Os objetivos deste artigo são os seguintes: por um lado, refletir sobre o fenômeno da viagem na Europa no século XVIII, sobre os seus significados e noções; em segundo lugar, a minha intenção foi recuperar as histórias e experiências dos viajantes espanhóis que entraram no país vizinho. A este respeito, nesta segunda parte vou tentar determinar o que tem sido o tratamento historiográfico deste grupo de viajantes, para finalmente fechar com uma análise da utilidade dessas histórias e experiências de viagem em Portugal para a História da vida diária.

Palavras-chave: viagem; século XVIII; vida diária.

\section{Voyageurs espagnols au Portugal du XVIIIe siècle: entre le connaissance et l'expérience}

\section{Résumé}

L'objectif que je me suis assigné dans ce travail est double: d'une part j’ai l'intention de réfléchir sur le phénomène du voyage en Europe au XVIIIe siècle, leurs significations acquis et les notions il s'identifie avec; et, deuxièmement, mon intention a été de récupérer les témoignages et les récits de ces voyageurs espagnoles qui s'engageaient dans le pays voisin. Dans ce sens, je marrêterai dans cette deuxième partie pour but de determiner qui a été le traitement historiographique de ce groupe de voyageurs — souvent méconnu — afin de conclure avec une analyse sur l'utilité que pourrait avoir le récit de ces expériences voyageuses au Portugal pour l'Histoire de la vie quotidienne. Mots-clés: voyage; XVIIIe siècle; vie quotidienne.

\section{Spanish travelers in Portugal in the 18th century: between knowledge and experience}

\section{Abstract}

The objectives of this paper are: reflect on the phenomenon of travel in Europe in the eighteenth century, paying particular attention to its various meanings and notions and recover the stories and experiences of those Spanish travelers who went into the neighboring country. In this sense, I'm going to study in this second part which has been the historiographical treatment of this group of travelers; and finally, my intention is to analyse the utility of this type of stories and experiences for the History of the daily life.

Keywords: travel; XVIII century; daily life; 


\section{El viaje como conocimiento y experiencia vital}

\section{Observar, conocer e informar}

Uno de los principales aspectos que me interesaba abordar cuando me dispuse a trabajar sobre los viajeros españoles que visitaron Portugal en el siglo XVIII era de naturaleza conceptual. Concretamente, me importaba determinar el significado o significados del fenómeno del viaje por Europa en el siglo XVIII. A reflexionar sobre este punto dedicaré, por tanto, el presente apartado que estará vertebrado por los conceptos de conocimiento y experiencia vital, pues en ellos encuentra carta de naturaleza la práctica del viaje en la centuria ilustrada.

Para hablar de conocimiento y experiencia en una dimensión más amplia que la que se suele considerar cuando se estudia el fenómeno del viaje en este período, hemos de tener en cuenta, antes de nada, que el viaje en el siglo XVIII no se reduce únicamente al fenómeno del Grand Tour, sino que, como tendremos ocasión de ver, asume muchas más formas e iniciativas. Como muy bien señala Mónica Bolufer, el Grand Tour "es sólo la manifestación más selecta y elitista de la experiencia del viaje: que en realidad es mucho más variada en sus formas, motivaciones y protagonistas" (2003, p. 259). De modo que, además de esos aristócratas de familias adineradas, fundamentalmente británicos, que realizaban su periplo por los principales países europeos como el culmen de un proceso de aprendizaje académico, social y cultural, ${ }^{2}$ encontramos viajando por Europa diplomáticos, comerciantes, militares, clérigos, burgueses y nobles - y no siempre hombres, como apunta Bolufer - , universitarios, eruditos de distinta naturaleza, amantes de las ciencias y las letras, etc. Es en este último grupo donde hemos de incluir a los viajeros españoles que transitan por Portugal en el siglo XVIII.

En segundo lugar, si pretendemos contemplar el viaje como un fenómeno amplio e integrador, que comprende distintos agentes y dinámicas, hemos de considerar también esos otros viajes que adquieren el carácter de desplazamientos más o menos cotidianos, realizados por el común de la población que transita por sus escenarios de vida. ${ }^{3}$ Porque el viaje, y no necesariamente aquel que se realiza únicamente a tierras lejanas o extrañas, sino el que transcurre por escenarios cercanos o de familiaridad, sirve también para moldear comportamientos espaciales y para construir concepciones o valoraciones sobre el propio entorno. Es este un asunto de cariz teórico que considero oportuno

\footnotetext{
${ }^{2}$ Hay que considerar el Grand Tour como un viaje iniciático, como el culmen de un proceso de aprendizaje social y cultural, pero también como un signo de ostentación social: mostrar al resto de la sociedad el estatus familiar de los jóvenes que lo llevaban a cabo. En este sentido, se trató de un fenómeno que acabó convirtiéndose en una moda entre la aristocracia y las clases altas europeas.

${ }^{3}$ Alicia Lindón (2006, p. 16) en su trabajo sobre las Ilamadas Geografías de la Vida Cotidiana explica conceptos tan relevantes para comprender estos temas como son los de: espacio vivido, escenarios de vida, escenarios de familiaridad, sentido del lugar, entre otros. Todos estos términos provienen de la Geografía Humana desarrollada desde paradigmas de la Geografía Cultural. La autora habla de Geografías de la Vida Cotidiana en plural puesto que se trata de un campo de la Geografía aún emergente, poco consolidado, que implica a varios planteamientos de la Geografía Humana. El objetivo de las Geografías de la Vida Cotidiana sería el estudio de "la relación espacio/sociedad a partir de la persona, del sujeto, del individuo".
} 
abordar puesto que nos permite establecer reflexiones generales sobre el fenómeno del viaje/viajes en el siglo XVIII.

Pero vayamos por partes. La primera cuestión que me planteaba al principio de este análisis era, por tanto: ¿qué significaba viajar en la centuria ilustrada? ¿Con qué nociones se identificaba el fenómeno del viaje en el siglo XVIII en Europa? Las historiadoras portuguesas Catarina de Castro y Ana Isabel Buescu aportan dos definiciones/interpretaciones del acto de viajar en el siglo XVIII que se corresponderían muy bien con aquello con lo que se identificaba este fenómeno en la Europa dieciochista. De Castro afirma que el viaje metaforiza la aventura del hombre en busca de conocimiento: "La itinerancia espacial traduce, en el fondo, el sempiterno esfuerzo del ser humano por revelar a sí mismo lo distante, lo diferente, lo exótico y lo desconocido y, consecuentemente, su deseo de engrandecerse" (2007, p. 15).

Ana Isabel Buescu, por su parte, apuntará que el viaje asume en la Europa del siglo XVIII "una importancia capital en la percepción de los espacios y de los hombres, en la reflexión sobre analogías y diferencias, en la adopción o rechazo de modelos" (1988, p. 27).

Elijo estas dos definiciones porque, como apunto más arriba, se muestran bastante acertadas con la noción de viaje que imperaba en la Europa del siglo XVIII, la cual se puede rastrear en la documentación primaria de la época. Una noción que venía a identificar viaje con conocimiento verdadero basado en la propia experiencia de la observación en primera persona. Los propios protagonistas así lo manifiestan en sus escritos. Por citar algún ejemplo, el francés Juan Bautista Labat (1664-1738) en su viaje a España realizado entre 1705 y 1706 escribía en el prólogo de su obra lo siguiente: "La máxima constante de un relato fiel que da sus viajes al público debe ser el no decir más que lo que ha visto por sí mismo; y cuando está obligado a informar de alguna cosa por el testimonio de otro, debe citar a aquellos de quienes lo ha sabido" (García Mercadal, 1999, p. 547).

Con el fin de optimizar este conocimiento sobre los lugares visitados, se escribieron obras a modo de guías de viajeros en las que se recogían consejos o exhortaciones sobre quéy cómo observar/conocer durante el viaje. Para España contamos con el artículo de José Clavijo y Fajardo: "Sobre algunos viajeros y modo de que los viajes sean útiles" publicado en el Pensador. ${ }^{4}$ En él expone Clavijo que "para instruirse no basta ver tierras, es necesario saber viajar". Todo buen viajero debe observar el gobierno de los pueblos, su sistema de legislación, naturaleza y espíritu de las leyes, pero también, debe introducirse en sus Ciertas y Artes, con el fin último, no sólo de informarse y conocer dichas realidades, sino de aprender de ellas. ${ }^{5}$ Para el caso portugués una muestra aún más

${ }^{4}$ Clavijo y Fajardo (1763). El pensador es uno de los semanarios más importantes de la segunda mitad del siglo XVIII. Obra de José Clavijo y Fajardo, fue impreso y distribuido en Madrid entre los años de 1763 y 1767. Está compuesto por seis tomos; cada número viene expresado a modo de pensamientos en los que Clavijo reflexiona, analiza, critica, etc. los aspectos más destacados de la sociedad de su época.

${ }^{5}$ Resulta interesante recoger las palabras de José Clavijo en las que hace referencia a este hecho: “Un hombre que hubiere viajado de esta manera, puede ser de gran utilidad en la República: de vuelta de su giro 
ilustrativa sería O peregrino instruído, texto escrito por el clérigo teatino nacido en Lisboa en 1658 Manuel Caetano de Sousa. ${ }^{6}$ Se trata de un manuscrito en el que su autor presenta una relación de más de 200 cuestiones acerca de aquello que debería ser observado durante un largo viaje al extranjero. De las 210 preguntas que componían el manuscrito sólo 19 hacían referencia a cuestiones del medio natural o físico, el resto estarían destinadas a recabar información sobre los aspectos morales de los habitantes. El estado moral debía tener, por lo tanto, primacía para el viajero, por encima del estado natural.

Conocerán el estado natural tomando noticia de la calidad del clima, del terreno, de los campos, de los montes, de los ríos, de las fuentes, de los frutos, de los ganados, de los minerales, de las aves y de los peces. Conocerán el estado moral de cada lugar tomando noticia del número de hogares, de los habitantes de los edificios públicos y particulares, del estado eclesiástico, político, militar y económico. ${ }^{7}$

En definitiva, se puede determinar que entre los historiadores que trabajan sobre el fenómeno del viaje en la Europa del siglo XVIII existe una tendencia clara por identificar viaje con observación y conocimiento de realidades sociales, políticas, económicas y culturales ajenas, diferentes o extrañas a las del sujeto que las contempla y registra. No me voy a detener en este punto ya que la extensa producción científica dedicada al estudio del viaje en el siglo XVIII deja bien claro en todas sus exposiciones este punto. Sílo voy a hacer, en cambio, en el apartado siguiente, donde subrayo otras interpretaciones sobre el fenómeno del viaje en la centuria ilustrada.

\section{Otras nociones del concepto de viaje en el siglo XVIII}

Cuando uno se sumerge en la lectura de los relatos de viajes y se detiene a estudiar pormenorizadamente su contenido relacionándolo con los aspectos teóricos pertinentes, así como a analizar la naturaleza del relato, se percata de que los sentidos del viaje, las nociones con las que se relacionaba este fenómeno eran muchas y más sugerentes.

De hecho, viajar en el siglo XVIII significaba, efectivamente, conocer, pero también contrastar informaciones previas, lo que llevaría a la afirmación de ideas preconcebidas o a su total rechazo; significaba, por tanto, perpetuar

debe conocer mejor a su misma nación [...] compara lo que ha visto fuera con lo que es práctica en su país, ve lo que le falta y lo que le sobra, toma de cada pueblo lo que le parece más digno de ser imitado y más análogo al genio de sus compatriotas, y acierta mejor con los medios que han de contribuir a una reforma que introduzca lo que falta y destierre lo que daña" (Clavijo y Fajardo, 1763, p. 163-164).

${ }^{6}$ Este documento ha sido fruto de algunos estudios especializados, como los realizados por Buescu (1988) o Tavares de Mello Abdalla (2012). Se sabe que la obra estaba destinada al joven rey portugués d. João V quien, parece ser, tenía pensado realizar un tour - que finalmente no se llevó a cabo - por distintos países europeos (España, Francia, Italia, Alemania, Holanda e Inglaterra).

7 Biblioteca Nacional de Portugal (BNP). O peregrino instruído. Devem aquelles que por meio das viagens querem conhecer o mundo, informarse en cada lugar do estado natural, eclesiástico, político y militar delle, códices 618 y 674 . 
estereotipos o construir otros nuevos. Viajar constituía además una práctica en la que intervenía irremisiblemente la memoria: el viajero rememora y recupera relatos e imágenes previas construidas por otros sobre un determinado lugar; relatos e imágenes que influirán en su percepción y representación de la realidad observada. Viajar era también, y sin perjuicio de lo afirmado en la línea anterior, un ejercicio creativo, puesto que de la apreciación, admiración o rechazo de lo observado surgirían imágenes nuevas - ¿o no tanto?; es decir, además del recuerdo, hay en estos relatos un componente importante de invención e imaginación, por lo que no sólo podemos hablar de repetición o perpetuación de ideas e imágenes. Finalmente - por poner un punto final a esta enumeración que podría ser más amplia —, durante el viaje se observaban diferentes realidades geográficas y sociológicas y al hacerlo se experimentaban contradicciones con la propia realidad geográfica y social del país de origen del viajero; contradicciones que conducirían a la adaptación y refutación de modelos, como afirmaba Ana Isabel Buescu o, como muy bien apunta Gloria Franco Rubio en un reciente artículo: "se producen trasvases culturales, desplazamientos e interferencias entre las dos tradiciones puestas en contacto" (Franco Rubio, 2010, p. 1).

\section{El viaje en el siglo XVIII no se reduce únicamente al fenómeno del Grand Tour}

Las nociones o significados del viaje en el siglo XVIII europeo van, por tanto, más allá de la mera observación/conocimiento. Se trata de un asunto más complejo, primero porque sus protagonistas y sus objetivos son heterogéneos: no olvidemos que los viajes que se realizan en el siglo XVIII responden a una gran cantidad de intereses y motivaciones (de hecho, hablamos de viajes de expedición, filosóficos, arqueológicos, políticos, militares, diplomáticos, etc.). Y segundo y fundamental: porque el viaje posee una dimensión personal nada despreciable que nos lleva a trazar una multiplicidad de significados y valores.

Todo viaje constituye una experiencia vital, un cambio o transformación en el individuo que lo experimenta a nivel personal (intelectual e incluso sentimental). Es de esa naturaleza del viaje como experiencia vital que se derivarían los significados que acabo de exponer: confrontación, comparación, perpetuación, repetición de estereotipos e imágenes o creación de otras nuevas, adaptación o rechazo de modelos, rememoración, invención, imaginación, construcción de representaciones sobre esas otras realidades observadas, desplazamientos culturales, transferencias, trasvases de información y comportamientos, etc.

Demos ahora un paso más en esta escala de reflexiones. Teniendo en cuenta estos sentidos o significados, el historiador debería interpretar el viaje en el siglo XVIII europeo: primero, como un instrumento utilizado para conocer, interpretar y valorar otras realidades sociales por parte de los individuos 
que lo llevan a cabo con el fin de constatar la alteridad, y a partir de ahí construir su propia identidad como ciudadano o la identidad de su país o región en oposición o correspondencia con las identidades o referencias observadas en el otro. ${ }^{8}$ Juan Pimentel abunda en esta idea al afirmar que los viajes de expansión resultaron fundamentales en la construcción del concepto de identidad europea, ya que ésta "surge siempre como toma de conciencia de la diferencia. La historia de la construcción de Occidente en la Edad Moderna es inalienable de la historia de su expansión" (Pimentel, 2003, p. 14). Segundo, desde la Historia social y cultural debería interpretarse el viaje como lo hace la profesora Franco Rubio, esto es, como un vehículo de influencias, interferencias y desplazamientos culturales entre tradiciones y realidades diferentes (Rubio, 2010). Y, en tercer lugar, completaría esta tríada de interpretaciones con la siguiente afirmación basada en la idea subyacente del viaje entendido como experiencia vital: el viaje, y no necesariamente aquel que se realiza únicamente a tierras lejanas o extrañas sino el que transcurre por escenarios cercanos o de familiaridad, sirve también para moldear comportamientos espaciales y para construir concepciones, percepciones o valoraciones sobre el propio entorno. Me refiero a los desplazamientos que realizarían a pie los miles de europeos o ciudadanos que en su cotidianidad se veían obligados a desplazarse a localidades vecinas - o no tanto - y que constituyen también un importante pozo de experiencias vitales para estos individuos.

Este tema sobre el que no suelen pronunciarse los historiadores, pero sílos geógrafos de la percepción, los psicólogos ambientales y algunos sociólogos y antropólogos, resulta interesante tenerlo en cuenta. Entre las interrogantes que vertebraban este trabajo destinado a desentrañar el concepto de viaje y a reflexionar sobre él, me detengo ahora en la que hace referencia a los miles de europeos, ciudadanos a pie, que no formaban parte de esa élite de privilegiados que viajaban a destinos destacados política y culturalmente, ni de ese grupo heterogéneo de militares, diplomáticos, comerciantes, nobles, burgueses, clérigos, estudiantes, etc. Qué significaría viajar para ellos. Es más, ¿podemos hablar, incluso, del concepto de viaje refiriéndonos a sus imaginarios colectivos?

Tratando de buscar respuesta a esta pregunta me encontré con la siguiente afirmación de François Moureau, un profesor de literatura francesa que lanzaba tajantemente la siguiente sentencia: "Para la mayor parte de los europeos, el viaje no existía. Atado a la tierra, el campesino, que formaba el núcleo esencial de la población de la época, no sabía incluso lo que significaba la palabra 'viaje"' (Moureau, 2005, p. 26).

\footnotetext{
${ }^{8}$ Como afirma Mónica Bolufer Peruga (2003) esta es una de las principales líneas por las que se viene preocupando la historia cultural: la de tratar de determinar el proceso de conformación de la identidad europea en el siglo XVIII y el papel que jugaron estos relatos de viajes en dicho proceso. Este es uno de los asuntos que aborda Peruga en este interesante artículo - que nos sirve de base para muchas de las afirmaciones recogidas en este trabajo a este respecto -, junto al de la percepción de la mujer concebida como signo y medida de civilización.
} 
A este respecto, considero que deberíamos matizar esta afirmación en función del contenido que le otorguemos al término del viaje, así como en función de la escala de análisis que decidamos emplear.

Como afirmaba unas líneas más arriba, desde la Geografía de la Percepción y la Psicología Ambiental ${ }^{9}$ se afirma que todo individuo que se desplaza por su entorno de familiaridad entabla con este una serie de relaciones que conducen a la asignación de unos significados que son únicos para dichos sujetos. Por lo tanto, los itinerarios cotidianos de los habitantes de las pequeñas ciudades o villas del siglo XVIII también suponen una adquisición de experiencias que vienen determinadas por las relaciones afectivas que estos individuos entablan con su entorno, con la adquisición de conocimiento de su realidad espacial. Experiencias particulares y significativas que les llevan, entre otras dinámicas, a moldear sus comportamientos espaciales.

Se puede alegar que más que de viajes, en este caso deberíamos de hablar de desplazamientos, o incluso de paseos, ${ }^{10}$ otro concepto con una carga simbólica bastante notable pero distinta a la del viaje, propiamente dicha. En parte es cierto. Si los traigo aquí es para dar cierta relevancia a estas dos prácticas cotidianas - el desplazamiento cotidiano y el paseo - vinculadas con la percepción y representación del espacio que pocas veces son consideradas por los investigadores. Pero, en este orden de cosas: ¿qué deberíamos decir sobre los desplazamientos a localidades aledañas o vecinas, a veces nada accesibles, por motivos laborales, administrativos o judiciales?

Se trata de contemplar otros contenidos y otra escala de análisis, por lo que no podemos concluir tan apresuradamente que esos miles de europeos que vivían en pequeñas localidades y que nunca participaron de ese circuito europeo no concibieran el viaje a la localidad vecina como una auténtica experiencia vital en la que en no pocas ocasiones ponían en peligro, incluso, su integridad física. ${ }^{11}$

\footnotetext{
${ }_{9}^{9}$ Para introducirse en este campo tan sugerente como es el de la Geografía de la Percepción se pueden consultar los trabajos de José Luis Vara Muñoz, José Estévanez y Constancio de Castro Aguirre. Por lo que respecta a la Psicología Ambiental, sigo los trabajos de María Amérigo, Juan Ignacio Aragonés y Enric Pol. Las referencias completas a estos autores están explicitadas en la correspondiente sección de bibliografía.

${ }^{10}$ Sobre la importancia del paseo como experiencia del entorno, que influye notablemente en el proceso de adjudicación de valores y significados paisajísticos se puede consultar la obra de Alonso Aguiló (2007).

${ }^{11}$ De estos desplazamientos a pie, cotidianos, de la gente anónima, no tenemos documentación escrita de primera mano, pero sí testimonios indirectos muy interesantes. En el Archivo histórico parlamentar de Lisboa he estado realizando una investigación en este sentido - que pronto será publicada -, consultando las respuestas que dan las cámaras concejiles a las propuestas de reorganización territorial que se les pretendía imponer con la Lei da Reforma das comarcas del año 1791. Esta ley pretendía una reorganización administrativa del territorio portugués que obligaba a cambiar la capitalidad de las comarcas, a reorganizar las circunscripciones administrativas, etc. Las cámaras concejiles realizaron consultas a los habitantes de sus respectivos concejos recogiendo las opiniones de éstos sobre dichos cambios, y muchos de ellos en sus respuestas van a hacer alusión reiterada al trastorno que les causaría pasar a depender de otra cabeza de comarca, o de otro juzgado. Entre los argumentos destacan aquellos que hacen referencia a los desplazamientos a ciudades o villas más lejanas a las que para llegar debían realizar lo que para ellos era un auténtico periplo en el que ponían en juego sus vidas: al tener que atravesar ríos caudalosos sin puente, lo que en invierno se cobraba algunas víctimas, o atravesar sierras impracticables por ser muy escarpadas, o atravesar descampados con el temor al ataque de lobos, o atravesar arboledas con lo que podían ser confundidos con ladrones. Un estudio detallado de estos testimonios nos da una idea de las preferencias espaciales de estos individuos, a dibujar lo que se ha llamado geografía del miedo - relacionada con espacios
} 
Por las propias características de estos desplazamientos a localidades más o menos cercanas, concebidos como verdaderos periplos - algunos realizados de forma más frecuente, otros más esporádicamente - , debemos considerarlos como fenómenos portadores de experiencias muy significativas para el individuo, puesto que es a partir de dichos desplazamientos que se consigue, como decía, moldear comportamientos espaciales, a la vez que coadyuvan a construir percepciones o concepciones sobre su propio entorno local o regional.

\section{Viajeros españoles en Portugal (siglo XVIII)}

\section{Tratamiento historiográfico de los viajeros españoles por Portugal}

Los viajeros de nacionalidad española - de los que tenemos constancia documental - que viajan por Portugal en el siglo XVIII no son muy numerosos, de hecho, se trata de un grupo bastante reducido sobre el que he podido obtener información bastante dispersa y fragmentaria. Quizá sea esta la razón por la cual se les ha dedicado tan poca atención por parte de la historiografía portuguesa y española - si exceptuamos un par de nombres como José Cornide o Francisco Pérez Bayer.

Por lo que respecta a estudios específicos que traten con una visión de conjunto a este grupo de viajeros españoles que se internaron en el país vecino durante la centuria ilustrada hay prácticamente un vacío historiográfico. Hasta ahora he podido localizar tan sólo algunos trabajos antiguos que les dedican una atención específica. Uno de ellos, el que los aborda desde una perspectiva más amplia es el de José Ares Montes quien proporciona además algunas pistas bibliográficas interesantes sobre determinados viajeros (1985). Por lo que respecta a autores portugueses, cito aquí dos trabajos antiguos de dos investigadores de cierto renombre en el mundo académico portugués: Fidelino Figueiredo, quien se centra en la figura de José Martínez Moreno (1947) y J. Leite de Vasconcelos, que focaliza su atención en el valenciano Francisco Pérez Bayer, ${ }^{12}$ siendo uno de los primeros en tratar la figura de este personaje (1920).

La historiografía portuguesa más actual que trabaja sobre la literatura de viajes se centra, fundamentalmente, en los viajes de expansión y descubrimiento en el ámbito ultramarino y cuando dirigen su mirada a los relatos de viajeros que transitan por su país, los reducen a los escritos por los autores extranjeros más conocidos, sobre todo británicos. ${ }^{13}$

abiertos, descampados, espacios sin arboleda;, a determinar los valores que se les da a determinados elementos del paisaje por parte de la población común. Y todo ello, a partir de estos viajes que constituyen auténticas experiencias vitales para los individuos que los han de realizar.

${ }^{12}$ La figura de Francisco Pérez Bayer ha despertado el interés de los arqueólogos y de los historiadores de la Antigüedad debido a los trabajos que desarrolló aquel erudito valenciano en dichos ámbitos. Por citar algunos ejemplos, contamos con los trabajos de Salas Álvarez (2007) y Mora (2003).

${ }^{13}$ Me refiero a los siguientes autores y sus obras: Henry Fielding y su Journal of a Voyage to Lisbon, 1755; Richard Twiss: Traves/ throuhg Portugal and Spain in 1772 and 1773, London 1775; el escocés William Dalrymple: Travels through Spain and Portugal in 1774, London 1777; Arthur William Costigan, (cuyo nombre verdadero era James Ferrier, un oficial escocés): Sketches of Society and Manners in Portugal, se corresponde con un 
A partir de la información que proporcionan estos estudios - más parciales que de conjunto, exceptuando el de José Ares Montes - sobre los viajeros españoles en tierras portuguesas, los apuntes dispersos sobre algunos de ellos presentes en trabajos más recientes como los de Manso Porto, y gracias también a los datos que suministran los repertorios bibliográficos que se realizan sobre los viajeros extranjeros en España y Portugal desde el siglo XIX, fundamentalmente el de Raymond Foulché-Delbosc, Arturo Farinelli, o el más reciente de Carlos García Romeral Pérez, ${ }^{14}$ he podido reunir alguna información sobre los siguientes viajeros y sus relatos sobre Portugal.

Joan Salvador Riera, Viatge d'Espanya i Portugal(1716-1717)(1972). Pertenecía a una famosa familia de naturalistas de Barcelona. Muy interesado por la botánica entró en contacto con la mayoría de botánicos de su tiempo, entre ellos, el famoso francés Antoine de Jussieu, quien le acompañó en este viaje.

Francisco Mariano Nipho, Descripción histórica y Geográfica del Reyno de Portugal 1762. Se trata de una descripción fundamentalmente geográfica, por lo que no podemos obtener muchos datos para el tema que nos ocupa. No es un relato de viaje propiamente dicho. ${ }^{15}$

\footnotetext{
viaje realizado entre 1778 y 1779 y se destaca en el ámbito de la literatura de viajes dieciochista por la imagen profundamente negativa que transmite de Portugal; James Murphy: Travel in Portugal, through the Provinces of Entre Douro e Minho, Beira, Estremadura and AAlém-Tejo, in the years 1789 and 1790, London 1795, un arquitecto irlandés que vino a estudiar in situ la arquitectura portuguesa y a diseñar esbozos de algunos de los monumentos más importantes del país, como el monasterio de Batalha y quien realizó un segundo viaje que le llevó a ampliar el relato anterior con el nuevo título: A general view of th estate of Portugal, 1798; Robert Southey: Letters written during a short residence in Spain and Portugal, cuya primera edición de 1797 se muestra poco favorable a Portugal ya que se transmite la imagen de un país semibárbaro y atrasado que, no obstante, sería corregida progresivamente en otras ediciones posteriores 1799 y 1806; William Berckford: escribió varias obras sobre Portugal y España a finales del XVIII y principios del XIX; están publicadas sus cartas, sus diarios de viaje, indispensables para conocer el Portugal en tiempos de la reina Doña María I. Otros autores y libros que se destacan, en lengua no inglesa, entre la literatura de viajes sobre Portugal en la segunda mitad del XVIII son los de Charles François Dumouriez: militar francés que permaneció más de un año en misión de espionaje en Portugal, publicó État présent du Royaume de Portugal, en Lánnée 1766; Carrère: Tableau de Lisbonne, 1797 - una de las obras más detractoras sobre Portugal-, Voyage en Portugal et particuléremente á Lisbonne ou Tableau Moral, civil..., 1798. Desoteux: Voyage du Ci-Devant Duc du Chatelet en Portugal; la obra del botánico alemán Heinrich Friedrich Link: Notas de uma viagem a Portugal e através de França e Espanha, un viaje que comienza en 1797; la obra del italiano Giuseppe Baretti o el de su compatriota Norberto Caimo, quien viajó por España, Portugal, Inglaterra, Bélgica y Francia durante el año 1755: Lettre d'un vago italiano ad un suo amico, 1759. Esta obra se ha considerado siempre como un libro antiespañol hasta que una revisión realizada por Noelia García Díaz en 2009 mostró lo contrario.

${ }^{14}$ La recopilación bibliográfica del hispanista Raymond Foulché-Delbosc publicada en 1896 en la Revista Revue Hispanique de París, que más tarde sería reeditada en Ámsterdam (1969) bajo el título: Bibliographie des voyages en Espagne et Portugal, reseña para el siglo XVIII a 94 viajeros que transitan por España y Portugal. De los viajeros españoles que se trasladan a Portugal sólo va a nombrar a Sebastián Sánchez Sobrino, con su obra Viaje topográfico desde Granada a Lisboa realizado en 1774 (aunque no sería editado hasta 1793). En cuanto al hispanista Arturo Farinelli, su obra más destacada fue publicada en 1920 bajo el título Viajes por España y Portugal desde la Edad Media hasta el siglo XX. Divagaciones bibliográficas. A ella se sumaría 10 años después El suplemento al volumen de las divagaciones bibliográficas (1930). En estas divagaciones bibliográficas incluye no sólo libros de viajes sino también descripciones, relaciones, itinerarios, memorias, recuerdos íntimos, diarios, diarios de campaña, viajes reales y fingidos, álbumes de fotografías y pinturas. Consultar a este respecto los apuntes publicados por Cantero (2000, p. 30-31). Más recientes son los repertorios elaborados por Carlos García-Romeral Pérez: Bio-bibliografía de viajeros por España y Portugal (XVIII), y Biobibliografía de viajeros españoles (XVIII) donde se da noticia de todos los nombres que vamos a tratar a continuación en este trabajo, con excepción del de Joseph Martínez Moreno.

${ }^{15}$ Francisco Mariano Nipho. Descripción histórica y Geográfica del Reyno de Portugal 1762 [BNP].
} 
Pedro Rodríguez Campomanes, Noticia geográfica del reino y caminos de Portugal, donde se describe este país con fines bélicos con el fin de facilitar a los ejércitos españoles la invasión de Portugal en 1762 (Molledo y Callén, 2006). En este sentido, el principal objetivo de la obra será la descripción de las vías de comunicación. Describe Portugal desde la perspectiva de las entradas a este país desde España. Asimismo, lo que más le interesa de las poblaciones citadas serán los aspectos militares.

Joseph Martínez Moreno viaja a Portugal en 1772 en compañía de José Cornide. Para este trabajo he utilizado como fuente la carta que escribe a Marcos Phelipe de Argáiz, que data de ese año. ${ }^{16}$

De Rafael Rodríguez Mohedano se conserva una carta escrita desde Lisboa en 1773 dirigida a su amigo Fray José Gálvez de Santa Teresa, su Provincial en Granada. ${ }^{17} \mathrm{Su}$ viaje a Lisboa se relaciona con el interés por entablar contacto con d. Manuel do Cenáculo. Como gran erudito de la historia, la lengua y literatura orientales, la pedagogía y la arqueología, Cenáculo fue un personaje que despertó el interés por parte de personalidades del mundo de las letras españolas como Rafael Rodríguez Mohedano (1725-1787), quien junto a su hermano Pedro - ambos monjes franciscanos - estaban escribiendo una Historia Literaria de España que se publicaría entre 1766-1791. Preocupado también por la decadencia cultural del país y de su ciudad, Granada, Rafael Rodríguez propone en 1762 un plan de estudios donde pretende promover estudios de griego y hebreo. En este contexto entra en contacto con Cenáculo, primero por carta y, más tarde, personalmente, cuando en 1773 realiza un viaje a Portugal del que se conserva la carta de la que hablaba más arriba. Y es que durante la segunda mitad del siglo XVIII surge en Portugal, al igual que sucedió en España, un gran interés por el estudio de las lenguas orientales. Un interés promovido, sobre todo, desde el Convento de Nuestra Señora de Jesús de Lisboa, sede de la Tercera Orden Regular Franciscana de Penitencia, impulsada por Fray Manuel do Cenáculo. He de apuntar aquí que, para los viajeros españoles, eruditos del mundo de las letras, las antigüedades, las ciencias naturales o la botánica, va a suponer un importante acicate esta figura, Manuel do Cenáculo, uno de los máximos representantes de la cultura de las Luces en Portugal. Este personaje jugará un papel indiscutible: nuestros protagonistas se van a sentir atraídos por la vasta cultura, personalidad y hospitalidad de este sabio portugués que actuará de excelente anfitrión de lo que dejan constancia en sus escritos. Es más, alguno de ellos confesará que el motivo principal de su visita al país vecino no era otro que conocer a este erudito de las letras.

\footnotetext{
16 "Carta de Joseph Martínez Moreno a Marcos Peliphe de Argáiz", 1772, publicada por Figueiredo (1947).

${ }_{17}$ Rafael Rodríguez Mohedano, Carta desde Lisboa a Fray José Gálvez de Santa Teresa, mayo de 1773, en Apología erudita de sus obras y otros papeles, Mss/12874, Biblioteca Nacional de España [BNE]. Para más información sobre Rafael Rodríguez Mohedano y su viaje a Portugal consúltese la obra de Martín Escudero (2011). Asimismo, sobre la producción literaria de los hermanos Mohedano se puede acudir al estudio de Mateu Ibars (1989)..
} 
Francisco Pérez Bayer (Valencia, 1711-1794) será uno de ellos. En su Diario de su viaje arqueológico a Andalucía y Portugal $1782^{18}$ este erudito español se sentirá atraído por los conocimientos de Cenáculo en Historia Antigua. En su palacio de Beja poseía una colección magnífica de inscripciones latinas que Pérez Bayer irá a copiar y a estudiar, entre otras antigüedades existentes en dicha ciudad. De hecho, no duda en declarar que sus motivos para desplazarse a Beja, más que por sus memorias romanas, fueron "conocer y tratar al ilustrísimo señor Don Fray Manuel del Cenáculo [...] sujeto de gran crédito en todo género de literatura, de quien había yo leído algunos opúsculos".

$$
\begin{aligned}
& \text { ¿Qué significaba viajar en la centuria ilustrada? ¿Con } \\
& \text { qué nociones se identificaba el fenómeno del viaje en el } \\
& \text { siglo XVIII en Europa? }
\end{aligned}
$$

Sebastián Sánchez Sobrino escribe Viaje topográfico desde Granada a Lisboa 1773 (1793). Lo hará bajo el pseudónimo de Anasthasio Franco de Brevinsáez y la obra no será editada hasta 1793.

De la extensa obra de José Andrés Cornide de Folgueira y Saavedra he usado para este estudio el diario del viaje que realiza a Portugal entre 1798 y 1801 y las cartas enviadas a su amigo López de la Torre Ayllón y Gallo desde Lisboa, ambos textos publicados por Abascal y Cebrián (2009). El gallego también se referirá a Manuel do Cenáculo como "la alhaja más completa que posee Beja, ya por su virtud y caridad, ya por su amor a los buenos estudios, como lo ha hecho ver en la inteligencia con que los promovió"; sin embargo, sus motivos trascendían el mero interés por encontrarse con este sabio portugués. En los años finales del siglo XVIII, concretamente en 1798, la Academia de la Historia le comisionó para que realizara un viaje a Portugal junto a Narciso Heredia, Melchor de Prado y Manuel Carrillo de Albornoz. ${ }^{19}$ Además de ampliar conocimientos en materia de arqueología y copiar el Códice de las Partidas custodiado en el Archivo de Torre do Tombo, en el país vecino deberían llevar a cabo una misión secreta encargada por Godoy: conocer y evaluar el potencial militar luso. Fruto de este viaje será la obra Estado de Portugal en el año 1800. Entregada a la Academia de la Historia un par de años después, no sería publicada por la institución hasta finales del siglo XIX (entre 1893 y 1897) en

\footnotetext{
${ }^{18}$ Francisco Pérez Bayer. Diário de viagem em Portugal, 1782. Publicado en Leite de Vasconcelos (1920).

${ }^{19}$ Como el propio José Cornide apunta en el diario de su viaje: "Narciso Heredia, natural de Almería, colegial de Santa Catalina en la Universidad de Granada, catedrático de Filosofía y Matemáticas en dicha Universidad, joven de 22 años instruido en las ciencias y en los idiomas; d. Manuel Carrillo de Albornoz, natural de Oaxaca, reino de Nueva España, y Don Melchor de Prado, natural de la ciudad de Santiago y Académico de mérito de la Real Academia de San Fernando en la clase de arquitectura; aquellos para ayudarme en la copia del Códice de las Partidas existente en el archivo de la cancillería de Portugal existente en el monasterio de San Benito de Lisboa y éste para hacer los dibujos de antigüedades e inscripciones", Diario del viaje a Portugal de 1798: Desde Madrid a Villaviciosa, 20 de octubre a 14 de noviembre de 1798 (Abascal y Cebrián, 2009, p. 318).
} 
tres volúmenes. No obstante, la realidad geográfica y social de Portugal había sido recogida por el ilustrado español con anterioridad: en 1764 había escrito su Descripción circunstanciada de la costa de Galicia y raya por donde confina con el inmediato reino de Portugaly, más importante aún, unos años después, en 1772, se tiene constancia del que sería su primer viaje peninsular en el que cruza la frontera portuguesa.

De este viaje de 1772 no se conocía prácticamente nada hasta hace muy poco tiempo por considerarse perdido el diario en el que se narraba este periplo peninsular. Así lo recogían los investigadores Juan Manuel Abascal Palazón y Rosario Cebrián en 2009 en lo que hasta ese momento constituía una de las obras más completas sobre los viajes de José Cornide. La información que suministraban acerca de este acontecimiento era bastante estricta. Señalaban que se trataba del viaje más largo de los emprendidos por el joven Cornide en el que atravesó Portugal desde el Norte (Braga, Oporto, Coimbra, Leiria y Lisboa) hacia el Sur, regresando a su tierra por Andalucía y Extremadura. También apuntaban que como testimonio de dicho viaje tan sólo se conservaba el mapa dibujado por su acompañante Joseph Martínez Moreno. Sin embargo, en 2010 apareció el libro de Mário Rui Simões Rodrigues donde se realiza un estudio minucioso de dicho viaje a partir del diario encontrado en la Biblioteca Nacional de Portugal.

\section{Experiencias de "lo cotidiano" en los relatos de viajeros españoles en Portugal}

\section{El viaje}

Una primera sistematización de los testimonios analizados nos lleva a distinguir un primer grupo que haría referencia a lo que podemos llamar la "cotidianidad del viaje", es decir, las experiencias que se derivan del viaje entendido como desplazamiento físico que conlleva una logística determinada, que se ve influenciado por distintos imprevistos (la climatología, por ejemplo), las características del itinerario (estado de los caminos), la disponibilidad de recursos y medios adecuados (medios de transporte, hospedaje), el estado físico o salud del viajero, las decisiones derivadas de sus intenciones o intereses, así como aquellas otras tomadas a última hora, etc. Estas declaraciones ayudan al investigador a formarse una idea de lo que suponía viajar por Portugal en el siglo XVIII, por lo que resultan bastante significativas.

Ninguno de estos viajeros se resiste a hablar de las condiciones en las que realizan el viaje, sobre todo, del buen o mal estado de los caminos, así como de los medios de transporte empleados. El botánico catalán Joan Salvador es el que más indicaciones da en la relación de su viaje sobre el estado de las vías, aunque éstas son bastante estrictas, limitándose a calificarlas de buenas o malas. ${ }^{20}$ Por su parte, Rafael Rodríguez Mohedano subrayará en su carta las

${ }^{20}$ El editor de la obra, Ramón Folch, describe el estilo narrativo de Riera como funcional, esquemático y directo, de hecho, dirá de él que no pretendía hacer literatura sino registrar lo que vio (Riera, 1972, p. 13). 
condiciones en las que realiza su viaje a Lisboa, sobre todo, en lo que respecta al hospedaje, hospitalidad, asistencia y trato de los naturales. Joseph Martínez Moreno también se va a referir, esta vez de forma específica, al mal estado de los caminos, pero no de aquellos distantes de la capital sino incluso de los que directamente llevan a ella:

Todos los caminos desde dos leguas antes de llegar a lo que llaman ciudad forman una calle casi poblada de casas a los dos lados. Es una confusión el gentío y con dificultad se halla quien dé noticia de las personas y casas más sobresalientes. No hay más arbitrio que andar a caballo o en ruedas. Este último hemos tomado alquilado un calesín por 42 reales diarios, pues además de evitar así los lodos, polvo, cansancio, rempujones, caídas, bacinadas, etc., logramos con mayor autoridad un cochero decano que sabe todos los rincones.

Resulta interesante reflexionar en este punto sobre un aspecto poco tratado en los estudios sobre los relatos de viajes: la influencia que ejerce el propio viaje - características y condiciones del itinerario, vicisitudes vividas por el viajante, etc. - en el contenido, estructura y estilo de la narración. Los acontecimientos, sucesos e incidencias del itinerario se traducen en cambios de ritmo, interrupciones y silencios en la estructura narrativa.

En este sentido, es posible comprobar algo que $a$ priori parece obvio pero de lo que no tomamos consciencia plena durante la lectura de este tipo de testimonios: cuando los caminos están en buen estado conceden al escritor la posibilidad de recrearse en el paisaje, de describir con mayor lujo de detalles las ciudades, villas o parajes por donde transitan; en cambio, las malas condiciones de las vías de comunicación le obligan a concentrarse en las incomodidades del camino, a descuidar la observación y, en consecuencia, el relato. Lo que se traduce en silencios, omisiones o pinceladas breves sobre determinados lugares.

Para conocer de forma pormenorizada la red de caminos principales y secundarios del reino de Portugal contamos con la obra de Pedro Rodríguez Campomanes. Describe Portugal desde una perspectiva muy concreta: las entradas a este país desde España. Así justificará en el prólogo que no comience su descripción por Lisboa como lo hace Juan Bautista de Castro en su Roteiro Terrestre de Portugal, ya que:

Esto sería útil a los portugueses que desde allí deben viajar como centro de su comercio, pero que no sucede lo mismo al que debe venir de fuera de Portugal, porque éste ha de ser guiado por el medio opuesto que es el de las diferentes entradas en el reino con dirección a la ciudad. (Campomanes, 1762)

Esta cita apoya mi afirmación de que ninguna narración geográfica, relación, memoria de viaje, etc., por muy descriptiva que parezca - como es este caso - , al ceñirse a la enumeración de vías, de caminos, etc., puede desligarse 
de la intencionalidad de quien la realiza y, por tanto, no puede dejar de considerarse subjetiva. Este es un ejemplo claro. La propia elección del orden en que se exponen las listas de poblaciones va modelando una geografía que sirve a los intereses de quien la elabora, así como del posible destinatario o lector. Los centros de interés de un país mudan en función de la perspectiva del observador. Así, Lisboa para Campomanes no sería el núcleo del país, el centro a partir del cual organizar su descripción, sino el punto de destino o llegada al que se pretende acceder desde España.

En cuanto a los medios de transporte, Francisco Pérez Bayer, de cuyo relato Leite Vasconcelos nos dirá que nos ofrece "una idea general del modo como se viajaba en Portugal en el último cuarto del siglo XVIII", en la relación de su viaje nombrará los medios empleados en sus diversos recorridos por la ciudad: la seggia, la caleça o la caleche. De la seggia nos dirá Cornide que este carruaje, propio del país, "cuesta ordinariamente entre 48 y 60 reis y se toma por días o medios días; es capaz de dos personas y rueda desde la mañana hasta la media noche" (Abascal y Cebrián, 2009, p. 782). ${ }^{21}$

Volviendo al relato de Pérez Bayer sobre las condiciones de su viaje, el valenciano se detiene en describir los requisitos administrativos necesarios para cruzar la aduana. A su llegada a Moura, hubo de identificarse y enseñar su pasaporte tras lo cual, el administrado de dicha aduana, d. Juan Marquez Vinhas, le entregaría la guía bajo su palabra de que una vez en Lisboa Pérez Bayer le enviaría la responsiva o tornaguía. Pero ahí no acababan los trámites. También debería presentarse ante el Secretario para que tomase razón de él y de sus "familiares". El Secretario se alojaba en una casa de campo, a donde tuvo que desplazarse nuestro viajero español. Una vez allí, le fue entregado un documento donde rezaba: "Francisco Pérez Bayer, español, caballero de la Orden de Carlos Tercero de España de edad de 70 años, estatura alta, cara ancha, ojos pardos, pelo raso, barba lo mismo, triguero dorado". También tomaron razón de su familia, refiriéndose a sus criados: "tres machos castellanos, dos castaños y uno negro, tres rocines, dos negros y uno gris".

El hospedaje, como vengo apuntando, constituye otro de los capítulos más tratados en los relatos, incluso en las cartas o en las descripciones breves. Quienes tenían oportunidad se hospedaban en las casas de aquellas personalidades civiles o eclesiásticas con las que entraban en contacto, casi todas ellas, relaciones entabladas a través de d. Manuel do Cenáculo. De este modo evitaban tener que hospedarse en posadas y mesones de baja calidad, que eran los que, por lo general, prevalecían en la geografía portuguesa. Rafael Rodríguez Mohedano dice hospedarse en Elvas en casa del Gobernador de la Plaza y Capitán General de toda la Provincia de Alentejo, d. Manuel Bernardo de Melo, a quien señala de "muy civil e instruido". En Évora se hospedó en casa de un Académico jubilado de Lisboa, "uno de los más eruditos" del reino. Dice que éste había recibido carta de d. Manuel do

${ }^{21}$ Se trata de una cita de Cornide extraída de sus "Notas a la descripción de Lisboa impresa en Ámsterdamen 1730” - descripción anónima de origen francés. Ms RAH 9-3899-68. 
Cenáculo instándole a recibirlo y que "desempeñó su encargo a la perfección”. Por su parte, Francisco Pérez Bayer, se alojaría unos días en la casa de d. Felix Cayetano de Sylva, "sujeto a quien después experimenté muy hábil y práctico de las antigüedades y otras memorias de Beja, de las cuales me enseño al día siguiente la Historia que había escrito".22

\section{Los acontecimientos, sucesos e incidencias del itinerario se traducen en cambios de ritmo, interrupciones y silencios en la estructura narrativa}

Estos testimonios nos ayudan a comprender que el viaje no era entendido únicamente como un medio para conocer nuevos lugares, sino que las relaciones de sociabilidad con las personalidades ilustres - ya fueran del ámbito político, administrativo, económico o cultural - se erigía en uno de los principales objetivos de estos viajeros. Entablar relaciones, crear contactos con figuras destacadas del panorama político-económico o cultural portugués formaba parte del proceso de conocimiento, formación y aprendizaje de estos viajeros, pero también de sus vivencias personales. Todo ello conformaba la experiencia con mayúsculas del viaje.

Cuando no tienen más remedio se hospedan en los mesones y posadas que encuentran en el camino y que según las descripciones resultan ser bastante incómodas y disponer de pocos recursos. Pérez Bayer, en el pueblo de Pedrogo, cerca de Moura, dirá que "allí comimos infelizmente porque ni había huevos (ni los hallamos en Moura), ni pescado, ni judías, ni fruta, ni cosa alguna. La dueña de la casa donde nos albergamos, porque tampoco había mesón, nos guisó un arroz que parecía puches".

Mejores son, en cambio, las hospederías de Lisboa. Dos son las de mayor fama entre los extranjeros: Estrela y Piamontesa. Eran muy frecuentadas por viajeros españoles; de hecho, nos refiere Pérez Bayer sus encuentros con un par de andaluces en esta última hospedería durante su estancia en la capital lisboeta, con quienes aprovechó para pasear por la ciudad.

Cornide abunda en este retrato más positivo del hospedaje en Lisboa al afirmar que "las posadas se han mejorado mucho desde el tiempo del autor". ${ }^{23}$ Las más "decentes" afirma que son las dos inglesas, ${ }^{24}$ Boavista y Calçada da Estrela,

\footnotetext{
${ }^{22}$ Francisco Pérez Bayer. Diário de viagem..., op. cit., p. 115.

${ }^{23}$ Se refiere al autor anónimo de la descripción de Lisboa impresa en Ámsterdam a la que hacíamos referencia en la nota anterior y que llevaba por título: Description de la ville de Lisbonne, ou l'on traite de la cour de Portugal, de la langue portugaise, et des moeurs des habitants, du gouvernement, des révenues du roi et de ses forces para mer et par terre, des colonies portugaises et du comerse de cette capitale.

${ }^{24}$ Según Francisco Rojas Gil - quien estudió las características de la hospedería en la España del siglo XVIII, aunque introduciendo referencias, además, a las portuguesas -, los extranjeros coparon parcialmente el empleo de posadero a lo largo del siglo. Se trataba de un sector en el que la presencia de extranjeros parece ser que era bastante notable, ocupándose gran parte de ellos en mesones, posadas y tabernas (Rojas Gil, 1978, p. 376).
} 
en las que "sale la comida, cena y almuerzo por 30 reis diarios y el cuarto se paga aparte y los hay desde 10 hasta 40 reis". También nombra las del Águila Negra (cerca de Cais de Sodré) y la del Isidro, donde se cobraban "24 reis incluso el cuarto y cama, pero el trato no es tan bueno, aunque muy decente; se come a mesa redonda y por poco más cada uno en su cuarto". En la casa de pasto de Las Caldas dice ser algo más barato. Y continúa con su relación diciendo que:

Hay muchas otras casas de pasto a donde sólo se da de comer, lo común por 12 reis, y cuanto a cafés, no son numerables. En Belem hay una buena casa de pasto cerca de la ribera y por 15 reis comí muy bien en un día de viernes. Otra cerca del Jardín Botánico, no tan buena pero más barata. Generalmente no se ponen servilletas ni tenedores a la española, sino garfios a la inglesa y del mismo gusto son la olla y los asados. (Abascal y Cebrián, 2009, p. 782)

A veces, las condiciones climáticas, el hambre o el cansancio les obliga a detenerse en el camino y prescindir de mesones y tabernas, "sin abrigo de cosa alguna, aguardando que fuese de día, pasando una malísima noche de frío, viento, etc." (Riera, 1972, p. 74), como se lamenta el botánico Joan Salvador Riera; o levantando tiendas de campaña improvisadas como la que erige Sebastián Sánchez Sobrino con adelfas y arbustos en el camino a Santa Olalla durante su viaje de Granada a Lisboa: "No hallé en todo el tránsito población, venta ni posada. Hice medio día en la Rivera, un arroyuelo de poca agua y muchos barrancos. Hice cortar adelfas y otros arbustos que me sirviesen de tienda de campaña mientras comía" (Sobrino, 1793, p. 21-22).

Estos testimonios, aunque breves, nos ayudan a conocer las condiciones generales del hospedaje en las ciudades y pueblos portugueses, que no se diferenciaban mucho de lo que se podía encontrar en España. Las descripciones de José Cornide, por su extensión resultan ser las más útiles para estudiar esta realidad, aunque no podemos desdeñar las de los demás viajeros, que como podemos observar, también arrojan datos interesantes sobre uno de los aspectos más importantes que conforman la cotidianidad del viaje.

La alimentación es otro capítulo destacado en estas experiencias de lo cotidiano. Se dan noticias de los productos más abundantes en cada pueblo en función de sus cultivos, o de aquellos de los que se carece. Incluso se aportan datos sobre los precios de determinados productos.

A este respecto, no son pocas las alusiones a las tierras de olivares y viñas que sorprenden y deleitan la vista de nuestros viajeros durante el trayecto, así como las zonas de vega y las huertas de frutales. De ello responsabilizan al clima de Portugal, "uno de los más benignos de la Europa". ${ }^{25}$ Francisco Mariano Nipho, a quien pertenecen estas palabras, continuará alabando las delicias de una naturaleza que "ha sido generosa con el Reino de Portugal en el repartimiento de los frutos, entre los cuales tienen el primer lugar el trigo, el vino y los aceites"; aunque tampoco escatima en las críticas en las que se vierte una

${ }^{25}$ Francisco Mariano Nipho. Descripción histórica y Geográfica..., op. cit., p. 8. 
imagen muy semejante a la que los teóricos, tratadistas, intelectuales, políticos, etc., daban sobre el estado de la agricultura en España: atraso de las técnicas, descuido del Arte de la cultura de la tierra y escaso amor al trabajo. ${ }^{26}$

A su paso por la provincia de Entre Douro e Minho, Joan Salvador Riera menciona que "la gente come mucho pan hecho de centeno, mijo y maíz, que ellos llaman "milho", no teniendo tampoco cebada blanca para las cabalgaduras, sino "maíz” (Riera, 1972, p. 86).

Cornide, más prolijo en detalles — también por la razón obvia de la mayor cantidad de documentación de la que disponemos sobre su viaje a Portugal de finales de siglo - , en otra de las cartas dirigidas a su amigo López de la Torre en enero de 1799 dirá que, por regla general, en Lisboa no hay nada más barato que el pescado "pues ahora mismo acabo de pagar tres lenguados medianos por seis reales de allá y una merluza harto grande me salió en ocho" (Abascal y Cebrián, 2009, p. 445). Esta información no debe llevarnos a engaño, pues Cornide, en las anotaciones o correcciones que realiza a la descripción anónima de Lisboa impresa en Ámsterdam en 1730, dirá, comparando los datos cedidos por el autor, que los precios de los comestibles se han doblado, de manera que:

\begin{abstract}
Un par de pollos [valen] 5 testones, una gallina, 7 a 8; la libra de vaca a 19 cuartos o 95 reis, el buen vino a 30 reis, etc. Los mejores jamones no son comparables con los de Galicia. El pescado ya está igualmente caro porque casi la mitad de lo que cogen se lo llevan de derechos la Casa de Bragança, y otras a quien la corona ha concedido esta regalía. (Abascal y Cebrián, 2009, p. 782)
\end{abstract}

En otro orden de cosas, aunque concerniente a este capítulo de la alimentación, Bayer introduce en la relación de su estancia en Portugal continuas referencias a los almuerzos, cenas y meriendas con las que es agasajado en las casas de las personalidades cuyas casas frecuenta, sobre todo, la de d. Manuel do Cenáculo. En realidad, no da muchos datos específicos pero su narración, metódica y sistemática, nos ayuda a conformarnos una idea de la rutina cotidiana de este prelado en su palacio de Beja, que transcurre entre invitaciones, conversaciones, tertulias nocturnas y meriendas con té y chocolate. También nos informa Bayer sobre lo que solía desayunar el erudito portugués: "un vaso grande de agua y un panete".

En la rutina del viaje de estos españoles también había lugar para la compra de lo que hoy llamaríamos souvenirs. Algunos de ellos nos refieren esta experiencia que no tendría mayor importancia si no es porque a través de ella se nos informa de los productos más valorados en Lisboa a finales de siglo, así como de las medidas proteccionistas aplicadas a determinados productos. De este modo, Pérez Bayer confiesa lo siguiente:

\footnotetext{
${ }^{26}$ Ibídem, p. 9. También hará referencia a las nefastas consecuencias de la "codicia de plantar viñas y limoneros inútiles" para beneficio de los ingleses y en detrimento de los intereses del pueblo portugués que contemplan pasivos cómo sus campos se van vaciando de otros productos de primera necesidad que se ven obligados a importar.
} 
Fui después a comprar tela para hábitos y cuatro baratijas para los amigos de Madrid y Valencia, y estuve entretenido viendo algunos géneros de India y China muy preciosos, así de seda como de algodón. Hubiera comprado alguna cosilla si no me hubiera detenido el justo recelo del peligro que puede haber de su introducción en España. ${ }^{27}$

Para finalizar con este primer grupo de observaciones sobre la cotidianidad del viaje, diré que tanto las condiciones climáticas, las horas de salida y llegada fijadas durante el itinerario, así como las condiciones físicas o estado de salud de los viajeros van a incidir en la exposición de la realidad que se nos presenta. A pesar de lo obvio del asunto, como decía unas líneas más arriba, pocas veces se incide en la estrecha relación que se establece entre las vicisitudes del viaje y el contenido y características narrativas del relato. Los retazos de realidad que se nos dibuja con palabras adolecen en ocasiones de algunos trazos en función de las condiciones bajo las cuales el viajante ha desarrollado su función principal: la de observar y narrar. Unas malas condiciones meteorológicas o una indisposición se traducen en el relato en saltos repentinos, en omisiones obligadas, en silencios desafortunados que ensombrecen la descripción de determinados lugares.

La indisposición que sufrió el malagueño Sebastián Sánchez Sobrino en Estremoz fue la responsable de que "pudiera advertir muy poco en esta posada" y que, en consecuencia, se lamente de que "desde aquí hasta Lisboa no pudiese satisfacer mi curiosidad como quisiera". El malestar fue tal que en Évora no pudo "ni aún pasearla toda, mucho menos investigar ni hacer crítica de sus antiguallas por mi indisposición, que no me dio lugar ni aún a abrir los ojos hasta Aldea Gallega". 28

\section{El universo cotidiano portugués}

Tras este repaso a las experiencias de lo cotidiano derivadas de aquello que venía a conformar la cotidianidad del viaje, paso ahora a comentar brevemente un segundo grupo de testimonios centrados esta vez en las observaciones que realizan los viajeros españoles sobre el universo cotidiano de los portugueses.

La vida económica de las ciudades, villas y lugares por las que pasan ocupan un lugar notable en sus descripciones. Se trata de datos sueltos presentados a modo de pinceladas o retazos dispersos entre los distintos aspectos recogidos en la narración, pero que nos ayudan a conformarnos una idea general

\footnotetext{
${ }^{27}$ Francisco Pérez Bayer. Diario de viagem..., op. cit., p. 155.

${ }^{28}$ Sebastián Sánchez Sobrino. Viaje topográfico..., op. cit, p. 28. Aldea Gallega era el lugar donde se encontraba el embarcadero para Lisboa. Las condiciones de la marea eran determinantes para realizar el trayecto, retrasando en no pocas ocasiones la partida a la capital. Francisco Pérez Bayer advertirá en este sentido que "el mar o la marea llega hasta el mismo embarcadero con el flujo o llena mar; pero en reflujo o bajamar se desvía del embarcadero un trecho bastante grande, y las embarcaciones que en aquel espacio coge se quedan encalladas allí hasta el día siguiente, en que el flujo o llena mar las levanta y vuelve a poner en movimiento" (Leite de Vasconcelos, 1920, p. 140). Por lo tanto, estas condiciones climatológicas o físicas determinarán también el itinerario y la rutina cotidiana de los viajeros.
} 
de la realidad cotidiana portuguesa en sus más diferentes dimensiones, sobre la que evidencian más las semejanzas que las diferencias entre los dos países vecinos. Se incidirá, fundamentalmente, en la vida económica de los pueblos (agricultura, ganadería y manufacturas), en su arquitectura doméstica, vestimentas, fiestas populares y dinámicas de sociabilidad.

Por tanto, se van a referir, como señalaba más arriba, a la producción agrícola de las distintas localidades, basada principalmente en la producción de aceite, vino, cereal (sobre todo el trigo, centeno, cebada y maíz), legumbres y frutales. Nipho nos da cuenta, además de los productos citados, de la importancia del lino y la lana en la provincia de Entre Duero y Miño, donde abunda también la caza y la pesca, al igual que en la provincia de Beira, donde el "terreno es muy fértil de trigo, centeno, mijo, ganados, caza, pesca y copiosas frutas, especialmente las de invierno". ${ }^{29}$ De Extremadura, a la que califica como la más fértil de Portugal, destaca sus salinas.

\section{En la rutina del viaje de estos españoles también había lugar para la compra de lo que hoy llamaríamos souvenirs}

La explotación del monte, perfectamente integrado en sus sistemas económicos como corresponde a toda sociedad de base orgánica como era la portuguesa a finales del siglo XVIII, jugará también un papel decisivo en sus economías domésticas.

En cuanto a las manufacturas, se referirán a determinados hitos, repetidos en casi todos los relatos, como por ejemplo los barros de Estremoz que constituían una partida importante de la alfarería tradicional, de uso cotidiano en los hogares portugueses. El botánico catalán Joan Salvador dirá de ellos que son de arcilla de color ocre que al ser pasada a fuego se vuelve roja y que adoptan diferentes figuras, destacando las grandes vasijas para acarrear agua (Riera, 1972, p. 69). Cornide también los nombra en sus notas y cartas:
Ya en el día hay nieve y helados que a proporción de la distancia no están fuera de precio, pues un vaso regular de agua cuesta 5 reis. La nieve viene de la Serra da Estrela [...]. Estos vasos de barro que, como las alcarrazas refrescan el agua, son los de Estremoz. (Abascal y Cebrián, 2009, p. 782)

Sánchez Sobrino mencionará en su Viaje topográfico esta producción, aunque en un tono no demasiado entusiasta: "hay fábricas de barros que aprecian mucho en el país aunque yo nada hallé en ellos de particular, ni en su color ni en sus hechuras" (Sobrino, 1793, p. 27).

${ }^{29}$ Francisco Mariano Nipho. Descripción histórica y Geográfica..., op. cit., p. 127. 
Esta es una de las manufacturas más comentadas por los viajeros españoles, junto a la fábrica de cristales de la que nos habla Josef Martínez Moreno y el ingenio de serrar madera "sin más impulso para el movimiento que el aire", ambos cerca de Leiria. Sobre esta fábrica de vidrios y cristales se referirá también José Cornide, alabando el buen gobierno y economía de la misma como consecuencia de la buena gestión del inglés que la fundó en dicho término de Leiria, concretamente en el sitio llamado la Ribeyra: "Que en el año de 1719 en que se empezó era un arenal y que ya en el día es una hermosa población, muy bien gobernada, pues hasta para diversión de los trabajadores en los días festivos ha establecido el dueño un teatrito a donde hacen sus representaciones" (Abascal y Cebrián, 2009, p.787).

Cornide será quien nos ofrezca de nuevo un panorama más completo de las manufacturas más destacadas..$^{30} \mathrm{~A}$ las de Estremoz y Leiria añade las de linos y algodones de Alcobaça y la de Tomar (donde se hilan estos últimos). Ya en la capital, en Lisboa, destaca el gallego la gran cantidad de manufacturas de telas pintadas, de sombreros de seda, de cajas y bandejas de charol y de peines de marfil, "que están a precios cómodos" (Abascal y Cebrián, 2009, p. 786).

Otro de los aspectos sobre los que más se detienen algunos de estos viajeros es el de la vestimenta de los aldeanos. No obstante, en sus testimonios no muestran tanta sorpresa o curiosidad como, por ejemplo, mostraban los viajeros británicos. De hecho, en este asunto encuentran más similitudes que diferencias, eso sí, según las regiones. Como era de esperar, en las localidades de frontera se comprueban ciertas semejanzas tanto en la vestimenta como en los comportamientos. Sánchez Sobrino cuando pasa por Santa Olalla en la provincia de Sevilla observa que:

Las mujeres visten pobremente y sobre la cabeza en pequeños rodetes llevan grandes cántaros de agua o cualquiera otra materia de peso (lo cual observé en todos los lugares de mi tránsito por la Extremadura hasta Badajoz y aún hasta cerca de Évora, dentro de Portugal); y equilibran de tal suerte estos cántaros sobre sus cabezas que vi a ocho mujeres bailar contradanza junto a una fuente, cada cual con el suyo, con tanto desembarazo y agilidad como si nada llevaran. (Sobrino, 1793, p. 23)

Joan Salvador Riera es uno de los que más datos aporta en este sentido. Son varios los testimonios que da sobre la vestimenta de hombres y mujeres a su paso por las distintas localidades portuguesas. Por ejemplo, cuando visita Roiolos, en el convento de San Joan de Loio, dirá que los monjes van de azul y con bonete, y las mujeres vestidas como los hombres, "menos las faldas, llevando la camisa de hombre, los cabellos cortos y anillados" (Riera, 1972, p.

${ }^{30}$ De estas manufacturas dirá Cornide que debido al aumento de la población lisboeta después del terremoto y del nuevo aumento experimentado por el alojamiento de tropas nacionales y extranjeras en su recinto y en algunos arrabales, y puesto que los precios de los productos de primera necesidad han doblado su precio, que es palmaria la escasez de leña, agua y materias primas, no pueden hacer frente estas producciones a las manufacturas extranjeras ni a las del resto del país, estando abocadas a la ruina. 
70). En Leiria, el día 4 de abril, domingo, había feria y durante la misma, nos relata Joan Salvador Riera cómo los paisanos que tenían armas y picas hacían ejercicios, estando formados, mientras que de las mujeres nos dirá un dato estricto pero llamativo: "van ya escotadas como en España" (Riera, 1972, p. 82). También describirá Riera el paisaje humano que encuentra en Coeixa el día de mercado, centrándose en la vestimenta femenina: "las mujeres van vestidas con unas faldas que por delante son abiertas y una parte solapa sobre la otra. En la cabeza llevan un velo de tela o de gasa blanco, y luego un sombrero" (Riera, 1972, p. 83). No se resiste tampoco a describir el uniforme de los estudiantes de la Universidad de Coimbra, quienes van con una capa larga hasta el suelo además de portar "una especie de bonete, de bayeta, que se ponen de diferente manera, pero la mayor parte de ellos lo lleva en la mano; otros iban de rojo, otros de blanco, etc." (Riera, 1972).

Para terminar, otros dos conjuntos de testimonios que completan este panorama de la vida cotidiana de la sociedad lusa - o al menos, de parte de ella-, son aquellos que nos describen las fiestas populares, sobre todo de carácter religioso, las ferias, romerías, etc., y los que hacen referencia a lo que hemos dado en llamar dinámicas de sociabilidad.

Una de las fiestas religiosas más destacadas por los viajeros españoles es la del Corpus Christi, la que llama poderosamente su atención por su magnificencia. Así nos lo relata Sebastián Sánchez Sobrino, quien duda de que se celebre otra igual en todo el mundo cristiano:

Así por la numerosa y lucida comitiva del clero secular y regular como por el adorno de la Estación, asistencia de Tribunales regios, de Órdenes Militares, de conciertos graves de música y de las personas reales que rodeados de la Corte Alta siguen a pie detrás del palio, todo con tanto decoro y majestad que respira la más tierna devoción. (Sobrino, 1793, p. 44)

Joan Salvador Riera describe en Lisboa la llamada Procesión de los Pasos en la que aparecen:

Diferentes penitentes que portan espadas, unos 24, otros 18, 12,6 , etc. Otros que van haciendo pasos y rezando el rosario [...] Después una cofradía y en medio, diferentes muchachos vestidos de ángeles con diferentes pasos de la pasión. Y al fin, Nuestro Señor con la cruz a cuestas. Acudía mucha gente [...]. Todas las mujeres están sentadas en calles y ventanas. (Riera, 1972, p. 77)

José Cornide, como no podía ser de otro modo, describe también algunas de las fiestas más populares que tienen lugar en Lisboa, como la del Corpus Christi, la Procesión de los Terceros, o la Romería de los Placeres que se celebraba en abril y donde había:

Una feria como la de San Bento, con rosarios de rosquillas, quesadas (especie de mazapanes), nueces, almendrucos, naranjas, muñecos, humo, aguardiente y licores y poca gente; es verdad 
que era sólo la víspera, pues la Virgen de los Placeres se celebró ayer lunes de Pascuilla. (Abascal y Cebrián, 2009, p. 465)

Finalmente, son interesantes los apuntes sobre la sociabilidad portuguesa, muy restringida, como advertía al principio de este estudio, a los círculos eruditos en los que se movían estos personajes. En este sentido, el relato de Pérez Bayer resulta valioso en tanto que nos describe de forma minuciosa los días que pasó en Beja con el obispo de dicha ciudad, d. Manuel do Cenáculo, lo que nos ayuda a hacernos una idea de la rutina cotidiana de este prelado en su palacio, así como de las relaciones sociales que entabla el valenciano con las personalidades con las que d. Manuel lo pone en contacto. Nos da cuenta de los momentos de ocio vividos en palacio y en la casa de personajes destacados de la sociedad portuguesa donde es invitado a conciertos de música o recitales de poesía. Reseñaré, por ejemplo, la velada que pasó en Évora, en casa del señor Maldonado donde le esperaban:

Varias gentes de distinción de la ciudad y algunos canónigos. Había también algunas señoras que hacían visita a la consorte (aún muy niña) y padres del señor Maldonado. Sirvióse un refresco decente de té con bizcochos (que es el estilo del país) y chocolate el que se añadió por mi respeto. Hubo varia conversación: las señoras me hicieron mil preguntas especialmente de Madrid y de Palacio y muy pormenor de la princesa de Asturias nuestra señora; los demás hablaron de diversos asuntos políticos y literarios. ${ }^{31}$

Muy interesante también es la descripción del concierto de música con el que lo lisonjearon en el palacio de su anfitrión, del que dirá lo que sigue:

Cantaba un Tiple Italiano que casualmente había ido a Beja desde Lisboa. Uno de los violines era seglar, los demás todos eclesiásticos o de vestido talar. Se tocó una sinfonía o un aria y en el intermedio el Maestro de Retórica de Palacio decía una pequeña arenga latina. Después el de Poesía recitaba un Epigrama. Todo era en elogio mío, lo que en medio de la gran merced que en ello me hacía su Ilustrísima, me causaba gran mortificación. ${ }^{32}$

No quiero extenderme más en estas citas. Con las recogidas hasta ahora creo dar una imagen lo suficientemente alentadora como para que los investigadores interesados en aspectos de la vida cotidiana tales como la alimentación, el vestido, las relaciones de sociabilidad, etc., se sientan motivados a acercarse a estos relatos, poco difundidos entre los estudiosos de la literatura de viajes.

\footnotetext{
${ }^{31}$ Francisco Pérez Bayer. Diario de viagem..., op. cit., p. 136.

32 Ibidem, p. 129.
} 


\section{Conclusión}

Con el fin de conectar a modo de conclusión el análisis documental de los relatos de viajeros españoles ${ }_{2}$ desarrollado en esta segunda parte del artículo con la disertación teórica expuesta en los primeros apartados sobre los significados y nociones del viaje en el siglo XVIII, quiero partir del amable reconocimiento que realiza nuestro ya conocido Rafael Rodríguez Mohedano sobre el carácter de los portugueses: "Amigo y dueño, aquí hay mucho obsequio, mucha verdad, mucha generosidad, mucho primor, mucha crianza, nada de grosería, nada de bajeza". Se trata de un ejemplo de la refutación de estereotipos e imágenes que permite el contacto en primera persona con la realidad que se pretende conocer.

La inevitable confrontación de las imágenes e ideas construidas a priori sobre la realidad territorial y humana del escenario portugués - en su mayoría procedentes de viajeros británicos- con la percepción y vivencia en primera persona conduce en este caso al reconocimiento del país vecino como un espacio físico y social donde son más evidentes las similitudes que las diferencias. A nivel económico, pese a las particularidades regionales, España y Portugal presentaban una economía de base orgánica. Además de por utilizar el sol como fuente básica de energía y de depender de la tierra para su desarrollo vital, este tipo de sistema económico se caracterizaba por disponer de unidades de explotación en las que se integraban perfectamente distintos espacios: el agrícola y el forestal. Algunos de los testimonios estudiados recogen esta realidad. Asimismo, la situación de la agricultura presentaría los mismos problemas en Portugal que los que ya se venían detectando desde hacía décadas en España: atraso en las técnicas y escasa inversión económica. Las observaciones de los viajeros españoles van dirigidas en este sentido: la riqueza de los recursos naturales lusos contrasta con la dejadez y el atraso en la gestión de los mismos.

Se encontraron, por lo tanto, con una situación económica que les resultaba bastante familiar. Del mismo modo, la fuerte impronta religiosa que impregnaba el universo cotidiano portugués tampoco suponía para ellos ninguna novedad.

En otro nivel de cosas, aquellos elementos de la cotidianidad portuguesa que llamaban la atención de viajeros de otras nacionalidades (sobre todo británicos), tales como la vestimenta, la alimentación, festejos y comportamientos de sociabilidad, para el español, en realidad, forman parte de su mismo universo cultural, por lo que no hay extrañamiento, sino todo lo contrario: reconocimiento de las semejanzas. Tanto en positivo como en negativo. No olvidemos que la queja continua al mal estado de los caminos, de las condiciones de mesones y hospederías, por no hablar de la calidad de los alimentos servidos en las mismas. Son estos comentarios comunes entre aquellos que se desplazan por España y Portugal - nacionales y extranjeros.

No obstante, la sorpresa se da y ésta se detecta de forma velada tras las continuas alabanzas a determinados aspectos o elementos de la realidad portuguesa: la fertilidad del suelo, las soluciones arquitectónicas, la suntuosidad de las celebraciones religiosas, la algarabía de los festejos, la variedad y calidad de los productos y el carácter amable, generoso y hospitalario de los portugueses.

Sin duda, estos testimonios ponen de manifiesto que la idea construida $a$ priori sobre Portugal - elaborada fundamentalmente a partir de los relatos de viajeros europeos - , aquella que dibujaba un país atrasado y sin cultura, no se correspondía con la realidad ante la que se encontraban los viajeros españoles. 


\section{Referencias bibliográficas}

ABASCAL, Juan Manuel; CEBRIÁN, Rosario. Los viajes de José Cornide por España y Portugal de 1754 a 1801. Madrid: Real Academia de la Historia, 2009.

AGUILÓ, Miguel Alonso (Coord.). Paseantes, viaxeiros, paisaxes. Santiago de Compostela: Centro Galego de Arte Contemporáneo, 2007.

ARAGONÉS TAPIA, Juan Ignacio. Mapas cognitivos: una revisión bibliográfica. Anales de Geografía de la Universidad Complutense, n. 8, 1988.

; AMÉRIGO CUERVO-ARANGO, María. Psicología ambiental. Madrid: Pirámide, 2010.

ARES MONTES, José. Viajeros españoles en Portugal entre 1700 y 1840. Estudios románicos dedicados al profesor Andrés Soria Ortega, Granada, v. II, p. 543-558, 1985.

BUESCU, Ana Isabel. O peregrino instruído. Em torno de um projecto de viagem setecentista. Revista da Faculdade de Ciências Sociais e Humanas, n. 2, p. 27-58, 1988.

CAMPOMANES, Pedro Rodrigues de. Noticia geográfica del reino y caminos de Portugal. Prólogo, Madrid: Joaquín Ibarra, 1762.

CANTERO, Nicolás Ortega. Relatos de viajeros por España y Portugal. Revista de Libros, n. 47, p. 30-31, 2000.

CLAVIJOY FAJARDO, José. Sobre algunos viajeros y modo de que los viajes sean útiles. Pensamiento XIX. El Pensador, t. 2, p. 159-188, 1763.

CRESPO COELHO CORREIA DE CASTRO, Catarina. Um livro negro sobre o Portugal do século XVIII. Casal de Cambra: Caleidoscópio, 2007.

DA GAMA CAEIRO, Francisco. Frei Manuel do Cenáculo: aspectos da sua actuação filosófica. Lisboa: Faculdade de Letras, 1959.

DE CASTRO AGUIRRE, Constancio. Mapas cognitivos. Qué son y cómo explorarlos. Scripta Nova: Revista Electrónica de Geografía y Ciencias Sociales, n. 33, 1999.

FIGUEIREDO, Fidelino. Viajantes espanhoes em Portugal. Boletins da Faculdade de Filosofia, Ciências e Letras, São Paulo, v. LXXXIV, Letras n. 3, 1947.

FRANCO RUBIO, Gloria. El viaje como laboratorio intercultural. Viajeros británicos y españoles en el siglo XVIII. Tiempos Modernos: Revista Electrónica de Historia Moderna, v. 7, n. 21, p. 1-35, 2010.

GARCÍA MERCADAL, José. Viajes de extranjeros por España y Portugal. Valladolid: Consejería de Educación y Cultura, 1999. t. IV.

GARCÍA-ROMERAL PÉREZ, Carlos. Biobibliografía de viajeros por España y Portugal (siglo XVIII). Madrid: Ollero y Ramos, 2000.

LEITE DE VASCONCELOS, José. El viaje de Pérez Bayer en Portugal en 1782. O Archeologo Portugués, v. XXIV, 1920.

LINDÓN, Alicia. Geografías de la vida cotidiana. En: LINDÓN, Alicia y HIERNAUX, Daniel (Dir.). Tratado de geografía humana. Barcelona: Anthropos, 2006. p. 356-400.

MADERUELO, Javier. El paisaje: génesis de un concepto. Madrid: Abada, 2007.

MANSO PORTO, Carmen. Cartografía histórica de José Cornide en la Real Academia de la Historia: el mapa general del Reino de Galicia y los de sus diócesis (1760-1772). Abrente, Boletín de la Real Academia Gallega de BBAA de Nuestra Señora del Rosario, n. 42-43, p. 237-302, 2010-2011. MARTÍN ESCUDERO, Fátima. Las monedas de Al-Andalus: de actividad ilustrada a disciplina científica. Madrid: Real Academia de la Historia, 2011.

MATEU IBARS, Josefina. Invitación para recordar manuscritos sobre ilustrados españoles: Pedro y Rafael Mohedano y su "Historia literaria de España". En: MARTÍNEZ DE SAS, María Teresa; PÉREZ SAMPER, MariaÁngeles (Coord.). Haciendo historia. Homenaje al profesor Carlos Seco. Madrid: Universidad Complutense, 1989. p. 143-149.

MORA, Gloria. La “erudita peregrinación”: el viaje arqueológico de Francisco Pérez Bayer a Italia (1754-1759). En: BELTRÁN FORTES, José; CACCIOTTI, Beatrice DUPRÉ RAVENTÓS, Xavier; PALMA VENETUCCI, Beatrice (Ed.). Illuminismo e ilustración: le antichità e i loro protagonisti in Spagna e in Italia nel XVIII secolo. Roma: L'Erma di Bretschneider, 2003. p. 255-275.

MOUREAU, François. Viajar por Europa en el siglo de las luces. En: ROMERO TOBAR, Leonardo; ALMARCEGUI ELDUAYEN, Patricia (Coord.). Los libros de viaje: realidad vivida y género literario. Madrid: Akal, 2005. p. 25-47.

PERUGA, Mónica Bolufer. Civilización, costumbres y política en la literatura de viajes a España en el siglo XVIII. Estudis: Revista de Historia Moderna, n. 29, p. 255-300, 2003. 
PIMENTEL, Juan Pimentel. Testigos del mundo: ciencia, literatura y viajes en la Ilustración. Madrid: Marcial Pons Historia, 2003.

POL I URRÚTIA, Enric. Psicología ambiental en Europa: análisis sociohistórico. Barcelona: Anthropos, 1988.

RIERA, Joan Salvador. Viatge d'Espanya i Portugal (1716-1717). En: GUILLÉN, Ramón Folch i (Ed.). Barcelona, 1972 [BNP].

ROGER, Alain. Breve tratado del paisaje. Madrid: Biblioteca Nueva, 2007.

ROJAS GIL, Francisco. Morfología del hospedaje en la Mancha en el siglo XVIII. Cuadernos de Historia, Estudios sobre el Siglo XVIII, n. 9, 1978.

RUI SIMÕES RODRIGUES, Mário. O diário perdido da viagem de José Cornide por Espanha e Portugal em 1772. Lisboa: Cepae, 2010.

SAFIER, Neil. Natureza narrada: representando o mundo natural nas expedições setecentistas. En: FERREIRA FURTADO, Junia (Org.). Sons, formas, cores e movimentos na modernidade Atlântica: Europa, Américas e África. São Paulo: Annablume, 2008.

SALAS ÁLVAREZ, Jesús. El viaje arqueológico a Andalucía y Portugal de Francisco Pérez Bayer. SPAL, n. 16, p. 9-24, 2007.

SALDANHA, Nuno. Memórias de viagem: um olhar europeu sobre o Portugal do século XVIII. Lisboa: CML, 2000.

SÁNCHEZ MOLLEDO, José María; NIETO CALLÉN, Juan José (Ed.). Viajes por España y Portugal: Pedro Rodríguez Campomanes. Madrid: Miraguano, 2006.

SOBRINO, Sebastián Sánchez. Viaje topográfico desde Granada a Lisboa 1773. Granada: Biblioteca Hospital Real de Granada [BHR], 1793.

TAVARES DE MELLO ABDALLA, Federico. O peregrino instruído: um estudo sobre o viajar e o viajante na literatura científica do Iluminismo. Disertación (Maestrado en Historia), Universidad Federal de Paraná, Curitiba, 2012.

VARA MUÑOZ, José Luis. Análisis de textos en geografía de la percepción: estado de la cuestión y bases conceptuales. Baética. Estudios de Arte, Geografía e Historia, n. 32, 2010.

. Cinco décadas de Geografía de la Percepción. Ería, n. 77, p. 371-384, 2008.

. Un análisis necesario: epistemología de la geografía de la percepción. Papeles de Geografía, n. 51-52, 2010.

VICENTE, Ana. As mulheres portuguesas vistas por viajantes estrangeiros: séculos XVIII, XIX, XX. Lisboa: Gótica, 2001. 